\title{
Age as a historical materialist concept in cultural- historical theory of human development
}

\author{
Idade como um conceito materialista histórico na teoria histórico-cultural \\ do desenvolvimento humano
}

Seth Chaiklin ${ }^{1}$

\begin{abstract}
The concept of age has a central role in the theoretical structure of L. S. Vygotsky's approach to analysing child development. This concept is presented in the first part of this article. The presentation is organized around three conceptual challenges, the role or function of the age concept in a theory of human development, the psychological "content" of an age, and how to evaluate development in relation to an age. Main points include: (a) age, as a psychological concept, is formed through historical, material practice, (b) the concept has practical importance, but (c) for the most part the concept is still only a theoretical sketch. The second part of the article takes up methodological problems involved in working with and further developing this theoretical concept. Use of the concept in relation to pedagogical interventions may be especially productive.
\end{abstract}

Key-words: age, social situation of development, zone of proximal development, cultural-historical theory of child development, Vygotsky \begin{abstract}
RESUMO
O conceito de idade tem um papel central na estrutura teórica da abordagem de L. S. Vygotsky para analisar o desenvolvimento infantil. Este conceito é apresentado na primeira parte deste artigo. A apresentação é organizada em torno de três desafios conceituais: o papel ou função do conceito de idade em uma teoria do desenvolvimento humano, o "conteúdo" psicológico de uma idade e como avaliar o desenvolvimento em relação a uma idade. Os pontos principais incluem: (a) a idade, como um conceito psicológico, é formada através da prática material histórica, (b) o conceito tem importância prática, mas (c) de modo geral, o conceito ainda é apenas um esboço teórico. A segunda parte do artigo aborda problemas metodológicos envolvidos no trabalho e no desenvolvimento desse conceito teórico. $\mathrm{O}$ uso do conceito em relação às intervenções pedagógicas pode ser especialmente produtivo.
\end{abstract}

Palavras-chave: idade, situação social de desenvolvimento, zona de desenvolvimento próximo, teoría histórico-cultural do desenvolvimento infantil, Vygotsky

\section{Introdution}

Ages. Stages. Epochs. Periods. Phases. Levels. These spatial and temporal words are sometimes used to refer to psychologically meaningful units in various cultural-historical works about child development (e.g., BOZHOVICH, 1978/1979; VYGOTSKY, 1933/1998; EL'KONIN, 1971/1999), but the specific meaning of these words and their interrelationships are often hard to discern. The present 
article explicates the significance of the concept of age within a cultural-historical perspective on human development, with a special focus on explicating the theoretical horizon within which Vygotsky was working. The focus on age reflects the fact that Vygotsky uses this concept consistently and centrally throughout his text on child development, while the other words are used more sporadically. The main aim of the present article is to support understanding of Vygotsky's conception of age in a way that enables one to investigate further in the spirit of this theoretical approach.

Especially from 1931 to 1934, Vygotsky worked on developing a systematic theory about the general structure and dynamics of child development, where age periodization was an important issue in this theory (VYGOTSKY, 1933/1998, p. 187). ${ }^{2}$ Three conceptual challenges must be confronted in understanding a cultural-historical concept of age: (a) the role or function of the concept within a theoretical conception of children's development, (b) the "psychological content" (or structure) of an age ("how an age period is defined"), and (c) how to evaluate children's development in relation to the content of an age ("why it is useful"). These three challenges are addressed and elaborated concentrating primarily on Vygotsky's theoretical efforts in relation to the concept of age. Taken together, these analyses provide a way to understand the meaning of the concept of age in Vygotsky's theoretical system, and more generally in a cultural-historical approach to development (at any age).

Main points that emerge from or underlie this article are: (a) the theoretical concept of age can be understood primarily as historical materialist in its intention, (b) the concept may be important and useful, with interesting implications worth exploring and developing further in developmental research (whether cultural-historical or some other theoretical perspective), but (c)

\footnotetext{
${ }^{2}$ Vygotsky worked on a book about child development, but did not complete this work. An important chapter in this planned book - a general theoretical discussion about the problem of age - may have been completed for publication by Vygotsky himself (EL'KONIN, 1971/1999, p. 13). El'konin was collaborating with Vygotsky during this time period, so there is a reasonable chance that El'konin had firsthand personal knowledge about the state of this chapter. Other materials for Vygotsky's intended book are available in the form of transcripts of lectures, outlines, or reading notes (e.g., RIEBER, 1998). The present article draws primarily on Vygotsky's (1933/1998) chapter for discussing an interpretation of the meaning of the age concept, and as an important source for Vygotsky's general theory of child development.
} 
methodological requirements for working with the concept are not adequately developed.

As will become apparent, Vygotsky's main accomplishment was to outline some general principles for formulating a theoretical perspective about the inner essence of development (along with sketches for the age periods from infancy through adolescence) as part of a theoretical conception of child development. It seems clear that Vygotsky only had sufficient time to sketch the outlines of the problem, without having the opportunity for further development. Therefore the concept of age remains an issue for further development and elaboration, rather than a solved problem or achievement of the first generation of cultural-historical researchers.

The present-day tasks are to understand the spirit of Vygotsky's theoretical perspective, to evaluate its continued value, and to consider open problems that deserve more attention. Simply being able to repeat or criticize Vygotsky's specific theoretical conception of age and child development will not advance the scientific understanding of child development. The spirit of Vygotsky's theoretical perspective on age is explained in sections 2 to 4 . Further theoretical and empirical work will be needed if one wants to continue to work with Vygotsky's approach to age. The article concludes with a series of methodological reflections (section 5) about the age concept, with a special focus on consequences for contemporary research.

\section{The role of age period in a holistic conception of child development}

As part of addressing the first mentioned conceptual challenge, it is necessary to address the additional challenge of understanding Vygotsky's theoretical conceptions. Even a casual reader of Vygotsky will notice that he does not usually engage in a common academic practice of making formal definitions of his key theoretical terms. Or he gives multiple or alternative definitions for the same term.

\subsection{Methodological approach}

Two different strategies are used here-both to understand Vygotsky's 
theoretical terms, and to understand his theoretical approach more generally. First, it is useful to grasp the general problems that Vygotsky was trying to address when he used the concept of age, because it will give some insight into how the concept was formulated. Second, a theoretical concept is always understood within a system of conceptual relations. It is not simply a matter of finding and interpreting a definition in one of Vygotsky's texts. The meaning of each individual theoretical term must be understood in relation to the entire theoretical system in which it appears. Therefore, the concept of age must be understood in relation to the entire theoretical conception of development with which Vygotsky was working, and in relation to the practical problems that Vygotsky was trying to solve with this theoretical system. The next subsection elaborates the general problems being addressed with the age concept. Key concepts are identified in section 2.4, and their systematic relations are discussed in sections $2.5,3$, and 4 .

\subsection{The general problems being solved - with a brief overview of other approaches to the problem of age periods}

The general scientific problem is how to conceptualize human development, where the concept of age is part of the scientific analysis. We know, as an empirical fact, that children and adults change over time - both physically and psychologically. Practical experience, especially with young children, is sufficient to notice changes in the content of their interests and activities as well as changes in psychological characteristics such as language, attention, and memory. As a historical fact, for thousands of years, these noticeable changes have been described in various systems of periods in human life. For example, the poet Solon (ca. 600 BC) describes ten periods of life, each lasting seven years; Hippocrates (ca. 450 BC) described seven stages of life, while Aristotle (ca. 325 BC) used three. These examples reflect the number of periods commonly used in different systems: 3, 7, or 10. A well-known (and often cited) example is found in Shakespeare's (ca. 1600) play As You Like It, (“All the world is a stage...") in which he describes seven ages of human life. 
Of course it is possible for anyone to arbitrarily divide children's lives into periods, but, as Vygotsky argues, these arbitrary methods usually focus on external features ("symptoms") of an age. For example, in the early $20^{\text {th }}$ century, divisions were often proposed by psychological and educational researchers on the basis of anatomical or physiological features, but, as Vygotsky also noted, these are largely empirical characteristics, not motivated by any theoretical reasons. The question or problem that Vygotsky sought to address was whether periods could be formed on a systematic, scientific foundation. More precisely: Can age periods be considered to have an objective reality (i.e., reflecting actual consequences of material processes), where boundaries between ages are placed according to objective criteria, not simply with arbitrary or freely chosen reasons (VYGOTSKY, 1933/1998, p. 188)?

It is striking that Vygotsky's chapter on age starts with the question of how to divide children's development into periods (p. 187) ${ }^{3}$ where the question of periodization is presupposed as a necessary scientific problem, without any need for comment or question. Given Vygotsky's commitment to a historical, materialist approach to psychology, he started with the assumption that age periods have an objective existence, where the scientific problem is to propose an empirically-motivated, principled psychological theory that explains the structure of these age periods, and the inner logic by which they are formed.

A second striking feature is that the question or issue of periodization is largely absent from most psychological research traditions that address child development; rarely acknowledged or recognized in contemporary developmental psychology. As a quick, rough indication of this situation, most of the 17 chapters (almost 1000 pages) in Handbook of Child Psychology: Vol. 1: Theoretical models of human development do not mention this issue (LERNER, 2006), with one main exception, a chapter on life-span psychology (BALTES; LINDENBERGER; STAUDINGER, 2006) - which does not appear in the 2015 edition of the Handbook. There is also a chapter on the life-course of individuals (ELDER;

${ }^{3}$ The 1998 English translation of the section heading "The Problem of Dividing the Child's Development into Periods" highlights the process of creating periods, but does not indicate that the word age is also included in the original text. The opening heading could be translated more literally as "The Problem of Age Periodization of Child Development." 
SHANAHAN, 2006, see also ELDER; SHANAHAN; JENNINGS, 2015). These chapters presuppose the necessity of age periods, given that their focus is a person over an entire life span, but there is no indication that these research approaches engage with or raise the theoretical question of how to define age periods, simply using them as a temporal sequence. There are also anthropological studies of age - looking at how particular societies or cultures organize social life in relation to age (e.g., KERTZER; KEITH, 1984; KERTZER; SCHAIE, 1989). The historical objectivity in these studies may be interesting and relevant for analyzing psychological age periods, but the logic in these anthropological studies is probably only loosely related to the concept of age as formulated by Vygotsky. All these works are interesting in relation to the cultural-historical concept of age, especially the empirical investigations of historical and normative questions, but it will require critical interpretation to draw on these works in relation to a cultural-historical theory of age - a task beyond the focus of the present discussion.

\subsection{General idea of age in cultural-historical theory}

The expression age (or age period) is understood as referring to a time period in a person's life history that has particular psychological characteristics. This way of using the expression age is much like the way the expression is used to refer to some cultural periods in the fine arts, such as the Golden Age (in Denmark) or the Silver Age (in Russia). These cultural periods are defined by essential internal characteristics (and not because of the particular years when they occurred). Similarly, age periods are understood as psychological periods that are historically and materially constructed - historically because the psychological functions that define a period are constructed through the history of human practices, materially because the functions are developed as a consequence of tasks and interactions with others. In this sense, age is used as an objective, historical materialist concept.

The lexical variations age and period, in Vygotsky's texts, are understood as alternative ways of speaking about or referring to the same phenomenon, the structure of psychological ontogenesis. The issues here are conceptual, not 
linguistic, despite the multiplicity of spatial and temporal words used (and the linguistic problems that arise when trying to translate terms from one language to another). ${ }^{4}$ With a clear account of Vygotsky's general theoretical conception, it should be possible to overcome ambiguities in interpreting the particular words used technically to indicate theoretical concepts. But the technical words alone will never be able to communicate these theoretical conceptions adequately, so it is likely that informal or everyday interpretations of these terms will continue to confuse the discussions, if persons are not aware of the special technical meaning. For example, words such as stage or period are often interpreted or understood in static and deterministic ways, while the conceptual intent in Vygotsky's theory is to refer to dynamic, interactive, emergent situations. The important issue is to seek to understand how an age is defined conceptually, even while problems of consistent, clear terminology will remain.

\subsection{Summary overview}

Here is a summary overview of the theoretical structure of Vygotsky's conception of child development, where the role of age periods is explained. This overview is elaborated in the following two sections, and supported with quotes from Vygotsky. Key concepts are: personality development, cultural development, consciousness, social situation of development, central neoformation, and age with stable and critical periods. The theoretical conception is holistic in three different senses, which are indicated in the next paragraph.

The main focus of a theory of child development is the development of the whole person (personality development), where each age involves a qualitative change in the general structure of consciousness. This focus on the whole person and consciousness as a whole are the first sense of holistic. Personality is expressed and develops through the development of psychological functions

${ }^{4}$ Lexical variation is found in the original Russian text, but sometimes the translator of the 1998 English version, has added the word level, when it is not found in the original text. There are, however, some instances of level that are found in the original. These are discussed in the present article. The terms epoch, stages, and phases, can also be found in Vygotsky's texts, especially when he is discussing Blonsky, who also used these terms, but there is no obvious systematic way in which Vygotsky used these terms. 
(cultural development). Consciousness is understood as an integral expression of the structure of personality (which depends on psychological functions), through which a person has a relation to the social environment. Psychological functions develop through participating in meaningful practices in this environment. This interactive relation between a child's current development (i.e. consciousness) and specific societal practices $^{5}$ is designated as the social situation of development ${ }^{6}$ of a given age. This is a second sense of holistic, where development of functions are understood in relation to meaningful wholes (i.e., practices). Cultural development (i.e. development of psychological functions) for a particular age period is organized around a central psychological neoformation, which is realized toward the end of an age period. A neoformation is a psychological (e.g., reasoning with concepts) or physical (e.g., walking) capability that has not been present yet in a person's development. The development of a central neoformation for a given age influences the development of other psychological neoformations for this age or the transformation of the role of existing formations. In other words, development is not a haphazard accumulation of diverse psychological capabilities, but an interaction between a child's capabilities and the demands of the social situation, where action in this social environment will support development of the central neoformation needed for the next age period. The social situation of development provides a structural relation between cultural development of psychological functions and the central neoformation. The bold theoretical idea is that the central neoformation is the criterion that demarcates one age period from another and the transformation of consciousness. The formation of this main psychological capability embodies the qualitative shift that distinguishes one age period from another, where existing psychological functions are restructured in relation to this new central formation, which also implies transformation of consciousness (because new relations,

${ }^{5}$ The word practices is used as a way to express what Vygotsky (1933/1998) has called (in translation) social reality (p. 198 and 199). It may also be possible (and appropriate) to translate the Russian expression as societal reality.

${ }^{6}$ It may also be possible to translate the expression as societal situation of development, which is more consistent with the idea of development in relation to societal practices. 
enabled by these new functions, are possible with the social environment). This is a third sense in which this theory is holistic because of this qualitative shift in consciousness from one age period to another. The shift from one age period to another is gradual, and punctuated each time with a critical period. The critical periods arise in connection with the development of a new central formation of a stable age. The change in consciousness enables a transition to a new set of societal relations, which also requires the development of new psychological capabilities needed in those new relations. At the same time, there may also be a process of giving up or modifying existing social relations from prior development. These disruptions in social relations are sometimes characterized as a crisis, because of the difficulties that arise in this change of consciousness. (See POLIVANOVA, 2000/2001, for more discussion.)

\subsection{Elaboration of summary overview}

Personality development and development of psychological capabilities ${ }^{7}$ are two different ways to express and think about the same phenomenon. In Vygotsky's (1931/1997a) words: "We are inclined to put an equals sign between the child's personality and his cultural development" (p. 242) or "The process of cultural development may be characterized as development of the personality and world view of the child" (p. 242). The idea of personality development is important theoretically in Vygotsky's approach, even though only a few pages in his collected works discussed this topic explicitly. For example, his monograph on higher psychological functions starts by asserting that the history of psychological functions has not been explored, and that this will be necessary "for proper understanding and logical elucidation of all aspects of the child's personality" (VYGOTSKY, 1931/1997d, p. 1). Bozhovich has the same evaluation about the centrality of the concept of personality in Vygotsky's approach. "In his own words, Vygotsky considered this problem to represent the pinnacle of all psychology"' (BOZHOVICH, 1988/2004, p. 24).

${ }^{7}$ The word capabilities is used instead of psychological functions. 
The term personality, as used by Vygotsky (1931/1997a), is a historical concept (p. 242), better understood as a relation that arises between person and the social environment as a consequence of his/her psychological capabilities, rather than a property or quality of a person. As Vygotsky (1931/1997a) notes, this concept does not refer to specific traits of individuality and uniqueness among persons (p. 242), which is also how the term is sometimes used in other psychological traditions and in everyday speech. ${ }^{8}$ Personality development refers to the whole person, not to diverse individual psychological components (p. 243).

Child development is conceived as a process whereby children grow into a societal practice through mastering external means, such as speech, writing, and mathematical operations, along with developing psychological capabilities such as will, intentional memory, and conceptual thinking. The appearance and elaboration of all these processes are examples of cultural development - in contrast to natural or organic development. That is, mastery of external means and psychological functions arise through participation in meaningful activities that were formed historically in human practices, rather than a maturation or unfolding of biological processes in the human organism. In other words, cultural development refers to mastering the historically developed forms of action, where cultural is being used to refer to "human culture" in opposition to biologicallybased developments that are independent of culture, and not in an anthropological sense that focuses on different human traditions of practice. A central focus in Vygotsky's approach to child development was to introduce a clear distinction between organic or natural development and cultural development (e.g., VYGOTSKY, 1931/1997d, p. 19-20; 1931/1997a, p. 239).

Age periods can be understood as a further specification and differentiation of the general idea of cultural development and personality development. The main problem in making a theoretical analysis of age is to identify the social situation of development and the central neoformation needed for the next age to develop (VYGOTSKY, 1933/1998, p. 195). "At each given age, we always find a

${ }^{8}$ Vygotsky also notes that the meaning of personality and world view are not precise, but it seems that he wants to use the idea of personality as a way to preserve a holistic perspective, while acknowledging that more conceptual development is needed. 
central neoformation seemingly leading the whole process of development and characterizing the reconstruction of the whole personality of the child on a new base" (p. 197). Being able to explain the cultural development of the child is the same thing as explaining the development of personality, where the focus on the interaction of different aspects in relation to the central neoformation, which is involved in the development of consciousness. For example for school age children (approximately 7-11 years old), the central neoformation (in Vygotsky's analysis) is conscious awareness and volition (or voluntariness) (VYGOTSKY, 1934/1987, p. 213). As a consequence of specific cultural developments, a person's way of relating to the world changes (because of new capabilities and knowledge). "At each given age period, development occurs in such a way that separate aspects of the child's personality change and as a result of this, there is a reconstruction of the personality as a whole" (VYGOTSKY, 1933/1998, p. 196). The central neoformation is not the only development that occurs in an age, but it is highlighted because this development is seen as the basic structure that provides the foundation for the next age. "The process of development in each age period ... represents a single whole which has a certain structure," even if there are complex and diverse partial processes that form this whole (VYGOTSKY, 1933/1998, p. 196). This point, and its theoretical significance, is elaborated in the next section, which takes up the second challenge about describing the structure of the age period.

The boundaries between one age period and another are indefinite (p. 191). Vygotsky acknowledges that critical periods have been discovered empirically, but he asserts additionally, without explanation, that these periods must necessarily appear between each stable period, as a result of theoretical analysis (p. 193). The particular empirical manifestations of critical periods may be different for each child, and must be evaluated relative to the child (p. 191-192).

\section{Content of an age}

Child development is conceptualized in terms of age periods, where each age period reflects a societally structured environment for action, and is characterized by the formation of certain dominant psychological capabilities 
(termed neoformation in Vygotsky's writings), that together can be understood as development of consciousness. To develop from one age period to another depends on the formation of central psychological capabilities that characterize and are needed for the next age period. These psychological capabilities are developmental because they enable qualitative changes in a person's ability to act in situated practices, which in turn engenders changes in a person's relations to the social environment (e.g., relation to others, motives, conceptions) (VYGOTSKY, 1931/1997a, p. 242; 1933/1998, p. 190; HEDEGAARD, 2014).

The expression content of an age refers to the idea that each age period has a structural and substantive content. The structure arises from the interaction between existing psychological capabilities and the demands in the social situation of development that results in the central neoformation, which is also the foundation for changes in a child's relation to the social environment. The societal practice, what Vygotsky called social reality, provides examples of actual forms of action, which are aimed at ideal forms (p. 203). These forms provide the content of social interaction that eventually becomes interiorized - what Vygotsky (1931/1997b) has called the general genetic law of cultural development (p. 106). "[T] he social environment is the source for the appearance of all specific human properties of the personality gradually acquired by the child" (VYGOTSKY, 1933/1998, p. 203). The substantive content of development refers to the particular central neoformation for an age period, and possibly to other psychological functions that are under development.

The essential point is that certain actions - in response to the demands of the social situation - are vital for the development of the psychological capabilities (central neoformation) that enable the next age period and engender a change in consciousness. This focus on a central neoformation and the social situation of development is the core of Vygotsky's theoretical solution to the problem of how to identify objective age periods. Development occurs as a consequence of the child's efforts to act in relation to the demands of societal practices in the social situation of development for a given age, and drawing on the forms of action that are present. It is not a process closed in on itself, or 
happening in parallel, nor are all actions sufficient to support development of the central neoformation.

Figure 1 - Interactive aspects in human developmpent

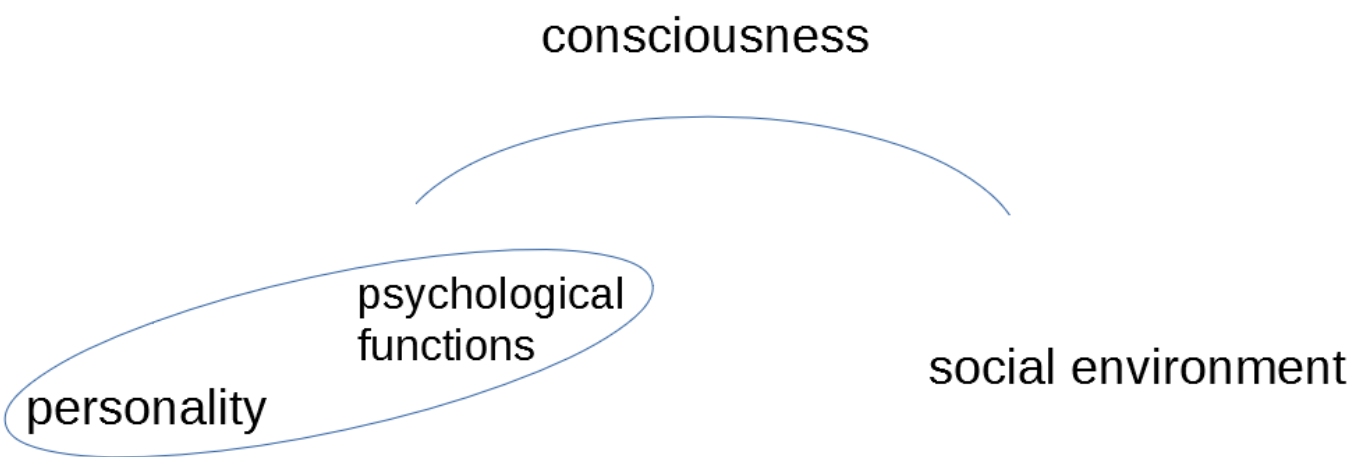

Font: Elaborated by the author.

Figure 1 provides a way to visualize the interactive nature of Vygotsky's (ontological) conception of psychological development. The components in the Figure are always in dynamic, interactive relations, where consciousness mediates a person's relation to the social environment (symbolized with the halfcircle), which influences how a person acts and interacts in relation to the social environment, which in turn has consequences for personality development. The circle around personality and psychological functions highlights that personality is expressed in and through psychological functions. At the same time, consciousness appears and develops from the interaction between personality (with its psychological functions) and the social environment, mediated through actions and interactions in the social environment. The figure does not show a linear or sequential process, where one aspect is prior to, causes or determines another aspect.

Underlying this interactive conception of development is a dialectical perspective, which Vygotsky (1933/1998) calls "the basic law of the dynamics of age" (p. 199). The appearance of each age period involves the creation of new capabilities, the loss or annulment of some capabilities, and the transformation of some capabilities. These characteristics reflect the general idea of Aufhebung 
(often translated into English as sublation), the term Hegel used to refer to the consequences of a dialectical transformation from one form to another. Vygotsky was familiar with this Hegelian idea. The underlying motivation for formulating this law (which should probably be considered a hypothesis) is to provide a way to think about and analyse the "internal causal-dynamic" (p. 203) of the development process. Vygotsky is oriented to using this analytic perspective because of a methodological principle from Marx (1894/1991, p. 956) about the need to distinguish between appearance and essence in scientific investigations (p. 188). This distinction motivates Vygotsky's interest to express the "internal essence" (p. 188) or "internal logic" (p. 192) of the process of child development, rather than describing appearances (symptoms) of development. (See CHAIKLIN, 2019, p. 265-268, for a more detailed discussion about these points, illustrated with the concept of "social situation of development".)

These methodological points are mentioned here to indicate the general conceptual structure that underlies Vygotsky's perspective for framing and approaching the problem of child development. Stable and critical periods are understood as consequences of dialectical transformation of personality, which is a result of action in the social environment, which is oriented by consciousness, which in turn serves to develop consciousness, through personality development. Reconstruction of the personality arises from the central neoformation and the changed relations to other formations, which yields a change in the general structure of consciousness (VYGOTSKY, 1933/1998, p. 197, 199). This dialectical perspective also underlies Vygotsky's view that critical periods are a necessary part of development, because "the internal logic of the process of development" is responsible for these disruptive periods (p. 192). These periods are engendered from transformations of consciousness, as a result the development of a central neoformation, which in turn create unstable conditions as a person tries to adapt to new relations to the social environment. The "severity" of the manifestation of the critical period depends on the external conditions, and must be assessed relative to the individual child. The focus on qualitatively different stable and critical periods resulting from dialectical transformation also explains why Vygotsky rejects an evolutionary view of development overall (p. 193), even while 
acknowledging within an age period there can be an evolutionary process (i.e., slow, gradual formation of new psychological capabilities over a longer time) ( $p$. 190).

\section{Evaluating development in relation to the content of an age}

Vygotsky's interest in development and age periods is motivated as much by practical as theoretical concerns. As a small indication of this interest: "The problem of age [level] is not only central to all child psychology, but is also the key to all problems of practice." (VYGOTSKY, 1933/1998, p. 199).9 This interest, which reflects the third challenge in understanding Vygotsky's concept of age, is explicated in this section. The point is to understand why the concept of age is important for issues of practice.

Especially for children, the social situation of development for a given age results from participation in pedagogical practices (e.g., upbringing, formal education). Choices by adults (e.g., parents, teachers) about how to conduct these pedagogical practices have important consequences for development. In particular, if one accepts (or works with) Vygotsky's theoretical conceptions about development, then pedagogical interventions should be oriented to supporting the development of the central neoformation of an age period. This is why age is the key to issues of practice. But to realize this vision, where interventions are relevant to development in an age, it is necessary to (a) know the central neoformation being formed in an age, (b) know how to assess a child's actual level of development ${ }^{10}$, and (c) compare the actual level in relation to the central neoformation needed for the next age period. Vygotsky (1933/1998) used the expression normative age[-level] diagnostics to refer to this set of analytic tasks

\footnotetext{
${ }^{9}$ The word level appears in the English translation, but is not indicated in the Russian text, therefore it is included in brackets, to quote the translation accurately, but to warn against using the word level here. The expression "problems of practice" could also be translated as "questions (or issues) of practice".

${ }^{10}$ Vygotsky (1933/1998) used the expression actual level of development to refer to this issue of determining a child's current level of development. The expression could also be translated as real level of development. In Vygotsky's chapter, this is the only expression where the word level is used consistently.
} 
(p. 204). ${ }^{11}$ He emphasized the distinct difference between a diagnosis that focuses only on the observable signs (symptoms) of child development from a diagnosis "based on the internal course of the process of development itself" ( $p$. 204). The idea of "internal course" is a reference to the dialectical scheme described in the previous section.

Age diagnostics involves the concept of zone of proximal development centrally, because the issue is to assess the difference between the actual level of development and the developing psychological functions that will become the central neoformation of an age period. The basic idea is that the psychological functions developing during one stable age period will become the central neoformation of the age, which results in development into the next age (p. 202). Vygotsky uses the expression zone of proximal development to refer to the difference between actual development of maturing functions and the central neoformation of the age. In this perspective, the meaning of zone of proximal development depends directly on the concept of age, where pedagogical interventions should be oriented to supporting the maturing central neoformation.

This general structural relationship between actual and coming development was described as the objective zone of proximal development for a given social situation of development (CHAIKLIN, 2003; 2011), to emphasize that all children in this social situation develop in relation to the same general ideal. Chaiklin also proposed to use the term subjective zone of proximal development to refer to the actual level of an individual child's development in relation to the objective zone of next development. It is interesting to note that Vygotsky (1933/1998) seems to have considered the zone of proximal development to apply to many different aspects of a child's personality development - but he explicitly skips over a discussion about this point (p. 203).

\section{Methodological reflections about the age concept}

\footnotetext{
${ }^{11}$ Again, the translator has introduced the word level, where there is no indication in the Russian text. The phrase could also be translated as normative age diagnosis.
} 
The article has focused so far on communicating central characteristics about Vygotsky's theoretical analysis of age, indicating some reasons for wanting or needing to use the concept. This section takes up a series of methodological questions with a focus on deepening the understanding of the age concept in a cultural-historical perspective, along with issues about how to continue to develop and work with the concept.

\subsection{Are adequate models of age already established?}

It should be clear that Vygotsky and others who have followed his lead such as El'konin and Bozhovich - have only produced further theoretical hypotheses. Both El'konin (1971/1999, p. 28-29) and Bozhovich (e.g., 1978/1979, p. 22) identify their proposals explicitly as hypotheses. ${ }^{12}$ Researchers who want to continue in this line of thinking must recognize that it is not sufficient to simply adopt the published results from Vygotsky (or Bozhovich or El'konin). Rather, one must try to understand the meaning of the concept of age, and recognize that it will be necessary to develop further hypotheses - ideally grounded in empirical analysis - if one is going to continue in the spirit of these ideas. Bozhovich (1977, p. 21) emphasizes how Vygotsky's theoretical constructions were grounded in empirical work, and, with reference to Vygotsky, she emphasizes the need to avoid premature theorizing.

\subsection{Must one always work with the age concept?}

From one point of view, it may seem unnecessary for many kinds of research interests to engage with or devote special attention to the idea of age period, especially when the research focus is on children's development within a particular age period, and with a limited focus on specific psychological functions or interactions. From another point of view, age is part of an integrated understanding of development, so attention to the idea of age period may have consequences for what is considered an interesting research question, or have

\footnotetext{
${ }^{12}$ Bozhovich and El'konin work further with the idea of age period, using the concept of leading activity to organize each age. At first glance this concept seems to serve a similar theoretical function as social situation of development.
} 
implications for appropriate or interesting interpretations of the results. For example, wouldn't it make sense for studies of development to have some explicit attention to a general theoretical conception of the developing psychological functions and their significance for the specific situation that one is investigating? In other words, rather than assuming that accumulations of investigations of specific phenomena will eventually yield an integrated perspective, attention to the concept of age would challenge one to consider the meaning of the specific investigation in relation to personality development and the psychological functions that are developing in relation to the next age. At the same time, as long as the content of the concept of age is underdeveloped in cultural-historical theory, then it is likely to be difficult to draw any conceptual advantage from working with the concept. By confronting this contradiction (e.g., by considering the meaning of specialized investigations in relation to an age), it is expected that some interesting or useful general perspectives will arise in relation to specific investigations, which in turn should help to better understand how to conceptualize an age.

\subsection{Is it worth pursuing the idea of age?}

Maybe it is impossible to make a scientifically grounded logic for age periods, but it seems like an ideal worth pursuing for now - in the expectation that it will bring us useful insights into child development. At the same time, it may be necessary to make some bold hypotheses, generated more rationally than empirically. For example, Slobodchikov and colleagues have developed a theoretical scheme of age periods (e.g., SLOBODCHIKOV; ISA'EV, 2000/2015; SLOBODCHIKOV; TSUKERMAN, 1996/2003). This scheme seems motivated more by rational analysis than empirical results - in contradiction to the empirical caution expressed by Bozhovich. This "chicken and egg" problem (i.e., whether to start with a theoretical model or to start with empirical analyses to build up a theoretical model) may have to be addressed simultaneously by working with theoretical hypotheses about age in interaction with empirical investigations, while accepting ambiguity and uncertainty, until sufficient theoretical and empirical experience is developed. The next section provides a 
methodological perspective both for thinking about this situation and for understanding underlying conceptual issues.

\subsection{A methodological perspective on the philosophical status of age period}

There are a whole series of "impossible" issues or questions that could be raised about Vygotsky's theory of child development. For example, Vygotsky uses the idea of central neoformation as a defining feature of each age period, and asserts that age periods should be understood as objective. What justification can be offered for these assumptions? It is unlikely that empirical evidence could be produced that would allow one to decide one way or the other about the validity of these theoretical concepts. And if the idea of central neoformation was dropped as the defining feature of an age period, then the question of what defines an age period would have to be re-opened. One could give up the idea of social situation of development, but then how will one analyse the direction or movement of development in relation to an age period? Or consider what would happen if the hypothesis of age periods were rejected? The entire theoretical system would unravel, because the concept of age is the main organizing structure for framing and analyzing child development. These kinds of proposals highlight the special necessity of key concepts in Vygotsky's theoretical system. But why preserve age period, social situation of development, and central neoformation as privileged elements in the theoretical system? This question must be answered methodologically; it cannot be resolved empirically. Lakatos's (1969) approach to the methodology of research programmes gives a useful way to address this question and other methodological problems in this theoretical perspective.

Lakatos suggests that a theoretical system is often organized around a "hard core" of assumptions, where these assumptions are maintained, no matter what, while other aspects in the theoretical system ("auxiliary assumptions") are adjusted or modified in order to preserve the hard core and maintain other desired scientific qualities (e.g., accounting for empirical observations, generating plausible explanations). As a simple illustration of how these ideas can be used 
to analyse a theoretical system: the Ptolemaic theory that the sun revolves around the earth is still valid - in the sense that its hard core assumption can be maintained, while introducing auxiliary assumptions (e.g., epicycles) that make it possible to account for empirical observations.

The appropriate evaluative principle in these situations is to consider whether the theoretical system remains progressive (as Lakatos calls it) - in the sense of helping to identify new phenomena and problems, providing explanations for existing empirical observations, generating interesting new ideas for investigation, and making predictions. A theory is maintained or rejected according to its qualities of being progressive. If the auxiliary assumptions that must be introduced to preserve hard core assumptions makes the theory complicated and difficult to work with, then a theory is likely to be rejected - not necessarily because it cannot account for empirical results - but because it is no longer progressive. In the case, of the Ptolemaic system, the introduction of epicycles (auxiliary assumptions) to preserve the hard core assumption (that the sun revolves around the earth) started to become computationally complicated, and the theory started to lose its progressive qualities, especially when compared with an alternative hard core assumption that the earth is revolving around the sun.

Applying this methodological idea of research programme to Vygotsky's theory about child development, we can understand that age periods, central neoformation, and social situation of development might be considered as part of a hard core of assumptions. Alternatively, maybe the ideas of personality development and objective age periods should be the hard core assumptions, where other auxiliary assumptions than a central neoformation would be used to define these periods. In this connection, it is relevant to note that Vygotsky (1933/1998) did not reduce all development to the central neoformation. He noted that there are also peripheral lines of development, of different capabilities and functions that were also developing, but in relation to the central neoformation. ${ }^{13}$

\footnotetext{
${ }^{13}$ El'konin (1971/1999) makes the same kind of statement in relation to leading activity (p. 27). A dominant or leading activity does not cancel or eliminate other activities, but the hypothesis is that the meaning or significance of other activities are modulated in relation to the leading activity.
} 
This flexibility or diversity in how to organize the theoretical analysis means that there is considerable freedom in being able to formulate a theoretical perspective about development. One useful implication of Lakatos's analysis is that it encourages one to think carefully about which assumptions are going to be considered part of the hard core (i.e., required), and what parts might be adjusted. Another useful implication is that it orients one toward thinking about whether the theoretical system is progressive or not - in the sense of being useful for generating new ideas, helping to discover new empirical issues, and so forth. The practical implication is that scientific efforts are best spent trying to use the theoretical perspective in investigating concrete problems, rather than trying to decide rationally whether it is true or correct. The preservation or modification of the theoretical system will depend on whether it is progressive in terms of generating ideas and useful implications and the complexity of the auxiliary assumptions. This perspective for theory evaluation is consistent with the practice orientation of cultural-historical research (e.g., VYGOTSKY, 1927/1997, p. 305-306).

This section has tried to give sufficient insight into an approach for evaluating the conceptual logic of Vygotsky's theory of child development so that present-day researchers can make wise (or at least self-consciousness) choices in working with and modifying the theoretical perspective.

\subsection{What is the "hard core" of a cultural-historical theory of age?}

This section first presents a proposal for general theoretical assumptions found and accepted in all existing cultural-historical approaches, not just Vygotsky's. This proposal can be understood as possible "hard core" assumptions that might be considered necessary for any cultural-historical approach to age or a provocation to develop another theoretical approach to age. Thereafter some points specific to Vygotsky's approach to age are noted.

The general points in any cultural-historical theory are:

1. practice assumption: development occurs through interaction in societally-meaningful practices

2. holistic assumption: focus on development of whole person 
3. holistic period assumption: an age is organized by a unified psychological whole

4. historical-materialist assumption: age periods are formed as a consequence of participation in historically-structured practices

5. qualitative shift assumption: change from one period to another involves a change in the unified whole

The first point reflects a historical-materialist perspective of cultural development. The second point reflects the focus on personality development as the focus of psychological theory, and also reflects the view about the need to understand psychological development as the interaction of humans in meaningful practices. The third point reflects the idea that psychological components develop in relation to each other in an integrated whole, which defines an age. The fourth point reflects a methodological point grounded in a dialectical perspective of development. The fifth point depends on the third and notes that each age period involves a qualitative shift in the psychological structure that characterizes an age.

There are also some specific points in Vygotsky's approach that are consistent with these five general points, but could be interpreted as auxiliary assumptions that concretize or elaborate the general points in the hard core. In particular,

1. central development assumption: one central neoformation as defining an age

2. alternating stable and critical periods

These points can be rejected or revised, without undercutting the acceptance of the hard core assumptions. By implication, other auxiliary hypotheses could be adopted, while preserving the basic core hypotheses of a cultural-historical theory of age. The main reason for raising these specific points is to illustrate that one could continue to work with the idea of age periods, without necessarily following all the details in Vygotsky's published formulation.

The central development assumption concerns the criterion used to define an age. Vygotsky has chosen to emphasize that there is a single central formation. This may be a productive model, but it is worth noting that one may 
be able to preserve the idea of historically formed age periods, but use other criteria for defining an age period. Some may want to argue that this assumption should be part of the "hard core," as a consequence of the other assumptions. My impression is that Vygotsky needed to have something like a central neoformation to be able to construct a dialectical perspective with qualitative shifts and a unified whole for each period (i.e., holistic period assumption and qualitative shift assumption). The idea of central neoformation may still be a valuable idea, but as the content of an age period in relation to a social situation of development gets elaborated, then it will be useful to examine whether the central neoformation serves to limit (or clarify) the characterisation of age. The second point concerns the necessity of critical periods. For example, El'konin (1971/1999) formulated a proposal that does not use critical periods as an explicit theoretical concept, even if he acknowledges empirical observations of crises around certain calendar ages.

\subsection{Is age period a normative imposition, hiding behind a scientific facade?}

Answers to this question must be formulated carefully. If age periods are objectively formed, then the "normative" aspect is reflected in the societal practice, in terms of the demands or expectations found in particular practices, and not in the preferences of the scientist. These normative demands are the background for how and why persons develop particular psychological capabilities. Cultural-historical theory seeks to avoid the imposition or creation of norms by researchers. This perspective stands in contrast to the predominant research traditions in child development, which have tended to focus on establishing norms that correlate age with particular psychological capabilities. In these perspectives, testing regimes are aimed at establishing norms (or a distribution) for a population of children, and evaluating children against these norms. Rose (1990), inspired by Foucault's (1975/1979) ideas about discipline, describes how the rise of schools and clinics in the early $20^{\text {th }}$ century gave conditions for psychologists to try to control children, with these kinds of approaches that served to capture or limit children (p. 142). This meaning of 
norm (which is based on empirical symptoms) stands in contrast to Vygotsky's focus on evaluating individual children, because Vygotsky is comparing individuals against the substantive achievement of an age (e.g., central neoformation) and not a statistical norm formed by measuring the performance of other children (see VYGOTSKY, 1933/1998, p. 205).

\subsection{Can the concept of age (period) be used in relation to adults?}

Vygotsky intentionally limited his focus to children up to the age of eighteen years (1933/1998, pp. 195-196). However, the general theoretical principles for how he has approached the concept of age seem like they could be adapted to work in relation to other age periods. One of the immediate problems to face are the criteria to be used for demarcating the periods. At first glance, it seems more difficult to identify a universal social situation of development for adults. It may be necessary to work with a more differentiated model that takes account of the social situation of development in the practices that give conditions for development.

\subsection{Does the concept of chronological age have any role in this theoretical system?}

The idea of chronological age does not appear to have a role in Vygotsky's theoretical system. This is understandable, given that he does not view development as a matter of unfolding already existing capabilities. From a practical point of view, we can understand chronological age gives a first, rough hypothesis about cultural age, but the important issue is to evaluate an individual child's development in relation to historically-formed age periods and development to the next age - which has nothing to do directly (in a causal sense) with chronological age.

\subsection{What are promising areas for future research?}

The problem of age is an important aspect in Vygotsky's theory of child development, but it is a topic that is rarely discussed or included in contemporary cultural-historical research. The present article has tried to illuminate the issues 
involved with this concept, both to show its possibilities and to show some of the many unanswered questions that remain. The most promising aspect of the concept is its challenge to think about the meaning of pedagogical intervention in relation to supporting development in relation to the next period. Creative interpretation of this general idea may serve to inspire important guidelines for developing pedagogical interventions in contemporary societal practices.

\section{References}

BALTES, P., B.; LINDENBERGER, U.; STAUDINGER, U. M. Life span theory in developmental psychology. In: LERNER, R. M. (org.). Handbook of child psychology: Theoretical models of human development. 6th. ed. Hoboken, NJ: Wiley, 2006. v. 1, p. 569-664.

BOZHOVICH, L. I. The concept of the cultural-historical development of the mind and its prospects. Soviet Psychology, v. 16, n. 1, p. 5-22, 1977.

BOZHOVICH L. I. (1978). Stages in the formation of the personality in ontogeny. Soviet Psychology, v. 17, n. 3, p. 3-24, 1979.

BOZHOVICH, L. I. (1988). L. S. Vygotsky's historical and cultural theory and its significance for contemporary studies of the psychology of personality. Journal of Russian \& East European Psychology, v. 42, n. 4, p. 20-34, 2004.

CHAIKLIN, S. The zone of proximal development in Vygotsky's analysis of learning and instruction. In: KOZULIN, A.; GINDIS, B.; AGEYEV, V.; MILLER, S. M. (org.). Vygotsky's educational theory in cultural context. Cambridge: Cambridge University Press; 2003. p. 39-64.

CHAIKLIN, S. A zona de desenvolvimento próximo na análise de Vigotski sobre aprendizagem e ensino. Trad. J. C. Pasqualini. Psicologia em Estudo, v. 16, n. 4, p. 659-75, Dec. 2011.

CHAIKLIN, S. Units and wholes in the cultural-historical theory of child development. In: EDWARDS, A.; FLEER, M.; BØTTCHER, L. (org.). Culturalhistorical approaches to studying learning and development. Singapore: Springer, 2019, p. 263-277.

ELDER Jr., G. H.; SHANAHAN, M. J. The life course and human development. In: LERNER, R. M. (org.). Handbook of child psychology: Theoretical models of human development. 6. ed. Hoboken, NJ: Wiley, 2006. v. 1, p. 665-715.

ELDER Jr., G. H.; SHANAHAN, M. J.; JENNINGS, J. A. Human development in time and place. In: BORNSTEIN, M. H.; LEVENTHAL, T. (org.). Handbook of 
child psychology and developmental science. 7th. ed. Hoboken, NJ: Wiley, 2015. v. 4, p. 6-54.

EL'KONIN, D. B. Toward the problem of stages in the mental development of children. Journal of Russian \& East European Psychology, v. 37, n. 6, p. 11-30, 1999.

FOUCAULT, M. (1975). Discipline and punish: The birth of the prison. Trans. A. Sheridan. New York: Vintage Books, 1979, 333 p.

HEDEGAARD M. The significance of demands and motives across practices in children's learning and development: An analysis of learning in home and school. Learning, Culture and Social Interaction, v. 3, n. 3, p. 188-94, 2014.

KERTZER, D.; SCHAIE, K. W. (ed.). Age structuring in comparative perspective. Hillsdale, NJ: Lawrence Erlbaum, 1989. 278 p.

KERTZER, D. I.; KEITH, J. (ed.). Age and anthropological theory. Ithaca, NY: Cornell University Press, 1984, 344 p.

LAKATOS, I. Falsification and the methodology of scientific research programmes. In: LAKATOS, I.; MUSGRAVE, A. Criticism and the growth of knowledge. Cambridge: Cambridge University Press, 1970. p. 91-196.

LERNER, R. M. (org.). Handbook of Child Psychology: Theoretical Models of Human Development. 6th. ed. Hoboken, NJ: Wiley, 2006. v. 1, 1085 p.

MARX, K. (1894). Capital: a critique of political economy. Ed. F. Engels; Trans. D. Fernbach. London: Penguin, 1991. v. 3.

POLIVANOVA K. N. (2000). Psychological analysis of the crises in mental development. Journal of Russian \& East European Psychology, v. 39, n. 4, p. 47-65, 2001.

RIEBER, R. W. (org.). The collected works of L. S. Vygotsky: Child psychology. Trans. M. J. Hall. New York: Plenum, 1998. v. 5.

ROSE, N. Governing the soul: The shaping of the private self. London: Routledge, 1990. $304 \mathrm{p}$.

SLOBODCHIKOV, V. I.; ISA'EV, E. I. (2000). The conceptual foundations of developmental psychology. Journal of Russian \& East European Psychology, v. 52, n. 5-6, p. 45-136, 2015.

SLOBODCHIKOV, V. I.; TSUKERMAN, G. A. (1996). Integral periodization of general psychological development. Journal of Russian \& East European Psychology, v. 41, n. 6, p. 52-66, 2003. 
VYGOTSKY, L. S. (1934). Thinking and speech. Trans. N. Minick. In: RIEBER, R. W.; CARTON, A. S. (org.). The collected works of L. S. Vygotsky: Problems of general psychology. New York: Plenum, 1987. v. 1, p. 37-285.

VYGOTSKY, L. S. (1931). Conclusion; further research; development of personality and world view in the child. Trans. M. J. Hall. In: RIEBER, R. W. (org.). The collected works of L. S. Vygotsky: The history of the development of higher mental functions. New York: Plenum, 1997a. v. 4, p. 241-251.

VYGOTSKY, L. S. (1931). Genesis of higher mental functions. Trans. M. J. Hall. In: RIEBER, R. W. (org.). The collected works of L. S. Vygotsky: The history of the development of higher mental functions. New York: Plenum, 1997b. v. 4, p. $97-$ 119.

VYGOTSKY, L. S. (1927). The historical meaning of the crisis in psychology: A methodological investigation. Trans. R. van der Veer. In: REIBER, R. W.; WOLLOCK, J. (org.). The collected works of L. S. Vygotsky: Problems of the theory and history of Psychology. New York: Plenum, 1997c. v. 3, p. 233-343.

VYGOTSKY, L. S. (1931). The problem of the development of higher mental functions Trans. M. J. Hall. In: RIEBER, R. W. (org.). The collected works of L. S. Vygotsky: The history of the development of higher mental functions. New York: Plenum, 1997d. v. 4, p. 1-26.

VYGOTSKY, L. S. (1933). The problem of age. Trans. M. J. Hall. In: RIEBER, R. W. (org.). The collected works of L. S. Vygotsky: Child Psychology. New York: Plenum, 1998. v. 5, p. 187-205. 